\title{
The Progins Progesterone Receptor Gene Polymorphism and Polymorphism of the Estrogen Receptor $\beta$ Gene in Endometriosis
}

\author{
Amal K. Seleem ${ }^{1}$, A. A. Abdel Aziz ${ }^{2}$, E. H. EL.Sayd ${ }^{3}$, Faeza el Dahtory ${ }^{4}$, \\ Eatimad A. Basha ${ }^{5}$ \\ '(Department of Biochemistry, Faculty of Medicine / Mansoura University, Mansoura, Egypt) \\ ${ }^{2}$ (Department of Gynocology, Faculty of Medicine/ Mansoura University, Mansoura, Egypt) \\ ${ }^{3}$ (Department of Chemistry, Faculty of Sciencel Port Said University, Port Said, Egypt) \\ ${ }^{4}$ (Department of Genatic, Children Hospital, Mansoura university, Mansora, Egypt) \\ ${ }^{5}$ (Department of Chemistry, ,central laboratories, Ministry of Health-Damietta, Egypt)
}

\begin{abstract}
:
Objective: To determine the frequency of the PROGINS polymorphism and the estrogen receptor $b$ gene (ER $\beta$ ) $+1730 \mathrm{G} / \mathrm{A}$ polymorphism in infertile women with endometriosis and fertile women.

Subjects and methods: Case-control study included 50 women with endometriosis, and 24 fertile women as control. The PROGINS polymorphism and the ER $\beta$ gene $+1730 \mathrm{G} / \mathrm{A}$ polymorphism were identified by Restriction Fragment Length Polymorphism - Polymerase Chain Reaction (RFLP-PCR).

Results: Genotypes A1A1, A1A2 and A2A2 (A2 representing the PROGINS polymorphism) of the progesterone receptor gene presented frequencies of $88 \%, 10 \%$ and $2 \%$, respectively, in the women with endometriosis. The allelic frequency of the PROGINS polymorphism was lower in women with endometriosis $(P>0.05)$ compared with healthy females in the patients with minimal/mild endometriosis $(p=0.978), 84.4 \%, 12.5 \%$ and $3.1 \%$, respectively, among the patients with moderate/severe endometriosis $(p=0.595) ; 94.4 \%, 5.6 \%$ and $0.0 \%$, respectively, and $83.3 \%, 12.5 \%$ and $4.2 \%$, respectively, in the control group. Genotypes GG, GA and AA of the ER $\beta$ gene presented frequencies of $56 \%, 34 \%$ and $10 \%$, respectively, in the women with endometriosis $(p<$ $0.05)$. In the control group; $91.8 \%$ presented the normal homozygous genotype GG, $8.2 \%$ the GA heterozygous genotype and $0.0 \%$ the homozygous mutated genotype AA.
\end{abstract}

Conclusion: The data suggest that the estrogen receptor gene $(E R \beta)+1730 \mathrm{G} / \mathrm{A}$ polymorphism may be associated with risk of endometriosis. In contrast, the PROGINS polymorphism does not seem to modify the risk of developing endometriosis.

Key words: Endometriosis, polymorphism, PROGINS, estrogen receptor $\beta$.

\section{Introduction}

Endometriosis is a steroid-dependent condition in which a tissue that is histologically similar to the endometrium with glands and stroma grows outside the uterine cavity and becomes implanted in tissues and organs such as the Fallopian tubes, ovaries, peritoneum, colon, the retrovaginal region and the bladder [1], being able to cause pelvic pain, dysmenorrhea and infertility [2]. Endometriosis affects 3\%-10\% of women in their reproductive years and $20 \%-50 \%$ of women with infertility [3]. Susceptibility to endometriosis depends on a complex interaction of immunologic, genetic and hormonal factors [4]. Many aspects of the female reproductive function are strongly influenced by genetic factors, and numerous studies have attempted to identify susceptibility genes for disorders affecting female fertility such as endometriosis [5]. Progesterone is a potent antagonist of estrogen-induced proliferation in the endometrium and may play a pivotal role in the pathogenesis of endometriosis. The human progesterone receptor (PR) gene is located at chromosome 11q22-23 and has two isoforms that modulate the biological action of progesterone: isoform $\mathrm{A}$, which is capable of inhibiting the activation of the estrogen receptors and isoform $\mathrm{B}$, which has the capacity to activate the estrogen receptors [6]. Several polymorphisms have been described for this gene, among which one stands out: a polymorphism named PROGINS, which arises due to the insertion of an Alu element into intron G between exons 7 and 8 of isoform A of the PR gene, resulting in an increase of $306 \mathrm{bp}$ in the gene product [7]. The estrogen receptor (ER) plays an important role in mediating estrogen action on target tissues. There are two isoforms of estrogen receptors, ER $\alpha$ and ER $\beta$, which are encoded by different genes [8]. ER $\alpha$ has a higher affinity for estrogen and is the predominant form in normal endometrium. Because large amounts of ER $\beta$ messenger ribonucleic acid (mRNA) are found in ovaries and granulosa cells, ER $\beta$ is likely to play a role in the ovulatory function [9]. Previous studies have demonstrated that both ER $\alpha$ and ER $\beta$ are expressed in human endometriotic tissues [10], but the distribution of the isoforms is different between eutopic endometrium and ovarian endometriotic tissues [11]. The $+1730 \mathrm{G} / \mathrm{A}$ polymorphismin of the ER $\beta$ gene was associated with an 
The Progins Progesterone Receptor Gene Polymorphism and Polymorphism of the Estrogen ...

increased risk of developing endometriosis, regardless of the stage of the disease [12,13]. Thus, the objective of the present study was to determine the frequency of the progesterone receptor gene polymorphism PROGINS and the $+1730 \mathrm{G} / \mathrm{A}$ polymorphismin of the ER $\beta$ gene in women with endometriosis and in control group.

\section{II.1 Patients:}

\section{Material and Methods}

In the present study, 50 patients with endometriosis-associated infertility were collected from Internal Medicine University Hospital, Mansoura University, Mansoura, Egypt, (mean age: 30.7. \pm 4.3 years) diagnosed by laparoscopy and classified by histological criteria according to the American Society for Reproductive Medicine. In the endometriosis group, $36.0 \%$ of the patients (32/50) had minimal or mild (stage I/II) and $34.0 \%$ $(18 / 50)$ had moderate or severe (stage III/IV) endometriosis. For the control group, 24 fertile women (mean age: 31.4. 4 .1 years) who had undergone tubal ligation, which allowed confirmation of the absence of endometriosis. Patients with endometriosis who did not achieve pregnancy after at least six natural or induced cycles following laparoscopy were considered infertile. All women whose partner had masculine factors involved with the infertility were excluded from the study. Clinical data and peripheral blood samples were collected only after explaining the objectives of the study and obtaining a signed informed consent form.

\section{II.2 Methods:}

DNA Extraction: Genomic DNA was isolated from fresh peripheral blood collected in EDTA tubes using Thermo Scientific Gene JET Whole Blood Genomic DNA Purification Mini Kit (Fermentas spin columns, Canada).

PCR:

PROGINS detection: Molecular analysis of the PROGINS progesterone receptor gene polymorphism was performed according to the protocol of Wieser et al.[14] with modifications. The primers used were 5'-GGC AGA AAG CAA AAT AAA AAG A-3' (forward) and 5'-AAA GTA TTT TCT TGC TAA ATG TC-3' (reverse). The PCR reaction was carried out in a final volume of $25 \mu 1$, containing $1 \mathrm{X}$ buffer, $2.5 \mathrm{mM} \mathrm{MgCl} 2$, $0.1 \mathrm{mM}$ of each dNTP, $50 \mathrm{nM}$ of each primer, $1 \mathrm{U}$ of Taq Polymerase(Invitrogen), and $200 \mathrm{ng}$ of DNA. Amplification was performed with an initial denaturation step at $95{ }^{\circ} \mathrm{C}$ for $7 \mathrm{~min}$, followed by 35 cycles of denaturation at $95{ }^{\circ} \mathrm{C}$ for $45 \mathrm{sec}$, annealing at $50{ }^{\circ} \mathrm{C}$ for $1 \mathrm{~min}$, and extension at $72{ }^{\circ} \mathrm{C}$ for $1 \mathrm{~min}$ and a final extension step at $72{ }^{\circ} \mathrm{C}$ for $7 \mathrm{~min}$. The amplification product was visualized in a $1.5 \%$ agarose gel under UV light. The PCR product presented a single band of $149 \mathrm{bp}$ in the homozygous individuals without the mutation, designated as A1A1. The presence of one 149-bp and one 455-bp band indicated heterozygous individuals, who have one allele without the mutation and one allele with the mutation; these individual were designated as A1A2. The presence of a single 455-bp band indicated individuals with the mutation in both alleles, and these individuals were designated as A2A2(Fig.1).

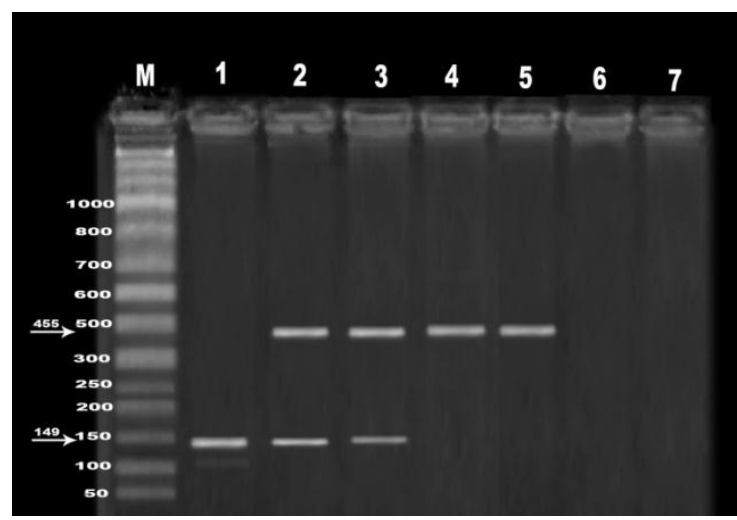

Figure(1): Agarose gel electrophoretic analysis of PROGINS progesterone receptor gene polymorphism: Lane

(M) represents the molecular marker (DNA molecular weight marker, purchased from promega Tecnical

Service,Catalog\#G3161). Lane (1) represents A1A1 that is presented by one band at $149 \mathrm{bp}$. Lanes (2 \&3) represent the A1A2 genotype that is presented by 2 bands at $149 \% 455 \mathrm{bp}$. Lanes (4\&5) represent the A2A2 genotype showing single band at $455 \mathrm{bp}$. Lane (6\& 7) represents negative control samples.

+1730 G/A OF ERß detection: A similar approach was used for the detection of the +331G/A polymorphism and +1730 G/A polymorphism. The primers used were: $5^{\prime}$-TTTTTGTCCCCATAGTAACA- 3' (forward) and 5'-AATGAGGGACCACAGCA- 3' (reverse). A G/A exchange at nucleotide 1730 in exon 8 introduces a recognition site for AluI. Digestion by AluI produces one band of $307 \mathrm{bp}$ in the normal ER $\beta$ sequence (GG); 
three separate bands of 307, 240, and $67 \mathrm{bp}$, respectively, in the heterozygous polymorphism (GA); and two separate bands of 240 and $67 \mathrm{bp}$, respectively in the homozygous polymorphism (AA) (Fig.2).

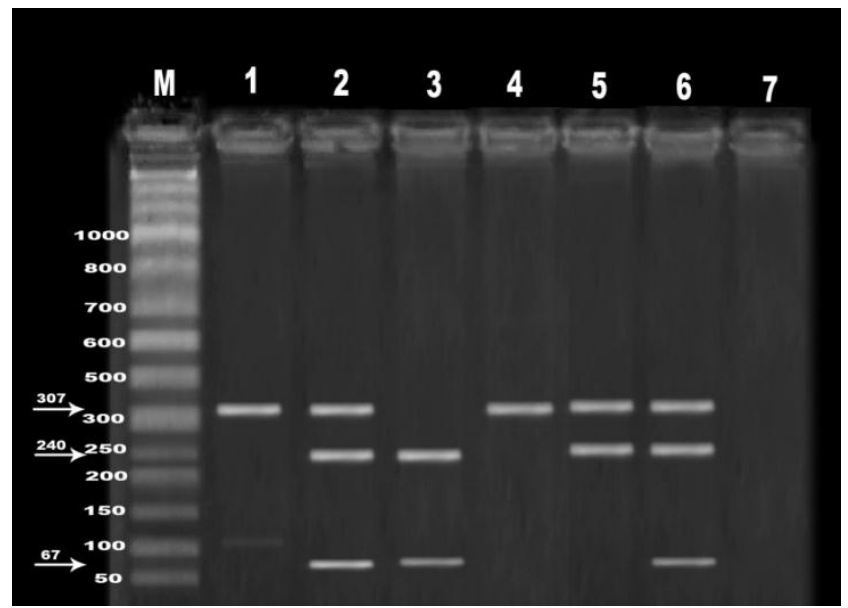

Figure(2): Agarose gel electrophoretic analysis +1730 G/A OF ER- $\beta$ Polymorphism after AluI digesion analysis: Lane (M) represents the molecular marker (DNA molecular weight marker, purchased from promega Tecnical Service,Catalog\#G3161). Lanes (1\&4) represents G/G genotype that is presented by one band at 307 bp. Lanes (2\&6) represents the G/A genotype showing three bands at 307,240 \&67 bp . Lane (3) represents the AA genotype showing two bands 240\&67bp. Lane (5): represent G/A genotype but the third band at 67 is not clearly seen.Lane (7) represent the negative control.

II.3 Statistical analysis: Allele and genotype frequencies were compared between groups using the $\mathrm{x}^{2}$-test or the Fisher's exact test. All p values were two-tailed, and 95\% confidence intervals (CIs) were calculated. A pvalue, 0.05 was considered statistically significant.

\section{Results}

PROGINS: Results are summarized in Table 1 and figures $3 \& 4$. The allele A1 homozygote (A1/A1) was the dominating genotype in the group of women with infiltrating endometriosis (88\%) and $83.3 \%$ in the control group. The overall frequency of the PROGINS complex of genomic alterations (A1/A2 heterozygote + A2/A2, homozygote) was $12 \%$ of patients with endometriosis and $16.7 \%$ in the control group. The A2/A2 homozygous PROGINS genotype was found in $2 \%$ of women with endometriosis and $4.2 \%$ of women in the control group. None of the observed differences were statistically significant. When the endometriosis group was subdivided with regard to the degree of endometriosis (grade I/II and grade III/IV), we did not find statistically significant differences (Table 2 and Fig. 5\&6). We also found no significant association between PROGINS polymorphism and personal habits such as physical exercise, smoking, alcohol consumption, and contraceptive use. Considering the alleles, allele A1 was present in $93 \%$ of patients with endometriosisassociated infertility, in $90 \%$ of women with minimal/mild endometriosis, in $97.2 \%$ patients with moderate/severe endometriosis and in $89.3 \%$ of the control group. Allele A2, on the other hand, was present in 7 $\%$ of patients with endometriosis-associated infertility $(\mathrm{p}=0.526, \mathrm{OR}=0.65,95 \% \mathrm{CI}=0.19-2.16)$, in $9.4 \%$ of women with minimal $/$ mild endometriosis $(\mathrm{p}=0.990, \mathrm{OR}=0.89,95 \% \mathrm{CI}=0.25-3.11)$, in $2.8 \%$ patients with moderate/severe endometriosis $(\mathrm{p}=0.231, \mathrm{OR}=0.24,95 \% \mathrm{CI}=0.03-2.20)$, and in $10.4 \%$ of the control group. The control group and infertile patients with endometriosis were in Hardy-Weinberg equilibrium (HWE).

$\mathbf{+ 1 7 3 0}$ G/A: Results are summarized in Tables 3. The allele $G$ homozygote (G/G) was $56 \%$ in the group of women with infiltrating endometriosis (Table 3 and Fig. 7\&8) and $91.8 \%$ in the control group. The overall frequency of the PROGINS (G/A heterozygote + A/A homozygote) was $44 \%$ in the group of women with endometriosis and $8.2 \%$ in the control group. The A/A homozygous of the ER $\beta+1730 \mathrm{G} / \mathrm{A}$ polymorphism was found in $10 \%$ of women with endometriosis and $0.0 \%$ in control group. Regarding the alleles, allele $\mathrm{G}$ was present in $73 \%$ of the patients with endometriosis and in $91.8 \%$ of the controls, whereas allele A was present in $27 \%$ and $8.2 \%$ respectively, showing a significant difference in the Allelic distribution related to control group $(\mathrm{p}=0.0007, \mathrm{OR}=8.51,95 \% \mathrm{CI}=1.93-37.48)$, in $23.44 \%$ of women with minimal $/ \mathrm{mild}$ endometriosis $(\mathrm{p}=$ $0.017, \mathrm{OR}=6.44,95 \% \mathrm{CI}=1.39-29.88)$ and in $36.1 \%$ patients with moderate/severe endometriosis $(\mathrm{p}=0.0005$, $\mathrm{OR}=13.00,95 \% \mathrm{CI}=2.70-62.53)$ as shown in table 4 and Fig. 9\&10.The control group was in HardyWeinberg equilibrium (HWE). The group of infertile patients with endometriosis was not in HWE.

Table 1. Genotype and allele frequencies of the PROINS polymorphism in endometriosis patients and controls . 
The Progins Progesterone Receptor Gene Polymorphism and Polymorphism of the Estrogen ...

\begin{tabular}{|l|c|c|l|l|l|}
\hline & patients group & \multicolumn{1}{|l|}{ Control group } & \multicolumn{1}{l|}{$\mathbf{X}^{\mathbf{2}}$} & \multicolumn{1}{l|}{ P } & Odd Ratio \\
\hline Genotype A1/A1 & $44(88 \%)$ & $20(83.3 \%)$ & \multicolumn{1}{|l|}{} \\
\hline Genotype A1/A2 & $5(10 \%)$ & $3(12.5 \%)$ & 0.002 & 0.660 & $0.76(0.17-3.48)$ \\
\hline Genotype A2/A2 & $1(2 \%)$ & $1(4.2 \%)$ & 0.044 & 0.538 & $0.45(0.03-7.64)$ \\
\hline GenotypeA1/A2 + A2/A2 & $6(12 \%)$ & $4(16.7 \%)$ & 0.035 & 0.718 & $0.68(0.17-2.69)$ \\
\hline Total No. & $(\mathrm{n}=50)$ & $(\mathrm{n}=24)$ & & & \\
\hline Allele A1 & $93(93 \%)$ & $43(89.6 \%)$ & & \\
\hline Allele A2 & $7(7 \%)$ & $5(10.4 \%)$ & 0.153 & 0.526 & $0.65(0.19-2.16)$ \\
\hline
\end{tabular}

Table 2.Genotype and allelic frequencies of the PROGINS polymorphism in stages of endometriosis patients

\begin{tabular}{|c|c|c|c|c|c|c|c|c|c|}
\hline \multirow{2}{*}{\multicolumn{2}{|c|}{ Population studied }} & \multicolumn{3}{|c|}{ Genotyping frequencies } & \multirow[t]{2}{*}{$\mathbf{P}$} & \multicolumn{2}{|c|}{ Allelic frequencies } & \multirow[t]{2}{*}{$\mathbf{P}$} & \multirow[t]{2}{*}{ OR $(95 \%$ CI $)$} \\
\hline & & A1/A1 & $\mathrm{A} 1 / \mathrm{A} 2$ & $\mathrm{~A} 2 / \mathrm{A} 2$ & & \begin{tabular}{|l|} 
A1 \\
\end{tabular} & $\mathrm{A2}$ & & \\
\hline \multicolumn{2}{|c|}{ Controls without endometriosis } & $20(83.3 \%)$ & $3(12.5 \%)$ & $1(4.2 \%)$ & & $43(89.3 \%)$ & $5(10.4 \%)$ & & \\
\hline \multirow{2}{*}{ Cases } & StageI/ Stage II $(n=32)$ & $2784.4 \%)$ & $4 \quad(12.5 \%)$ & $1 \quad(3.1 \%)$ & 0.978 & $58(90.6 \%)$ & $6(9.4 \%)$ & 0.990 & $0.89(0.25-3.11)$ \\
\hline & $\begin{array}{c}\text { Stage II/Stage IV } \\
(\mathrm{n}=18)\end{array}$ & $17(94.4 \%)$ & $1(5.6 \%)$ & $0(0.0 \%)$ & 0.595 & $35(97.2 \%)$ & $1(2.8 \%)$ & 0.231 & $0.24(0.03-2.20)$ \\
\hline
\end{tabular}

Table 3. Genotype and allele frequencies of the ER $\beta+1730 \mathrm{G} / \mathrm{A}$ polymorphism in endometriosis patients and controls .

\begin{tabular}{|c|c|c|c|c|c|}
\hline & Patients group & Control group & $\mathbf{X}^{2}$ & $\mathbf{P}$ & OR $(95 \% \mathrm{Cl})$ \\
\hline Genotype GG & $28(56 \%)$ & $22(91.8 \%)$ & & & \\
\hline Genotype GA & $17(34 \%)$ & $2(8.2 \%)$ & 5.405 & 0.011 & $6.68(1.39-32.04)$ \\
\hline Genotype AA & $5(10 \%)$ & $0(0.0 \%)$ & 2.063 & 0.075 & $8.68(0.46-165.49)$ \\
\hline Genotype GA + AA & $22(44 \%)$ & $2(8.2 \%)$ & 7. 856 & 0.003 & $8.64(1.83-40.78)$ \\
\hline Total No. & $(\mathrm{n}=50)$ & $(n=24)$ & & & \\
\hline Allele G & $73(73 \%)$ & $46(95.8 \%)$ & & & \\
\hline Allele A & $27(27 \%)$ & $2(4.2 \%)$ & 9.332 & 0.0007 & $8.51(1.93-37.48)$ \\
\hline
\end{tabular}

Table4.Genotype and Allelic frequencies of the ER $\beta+1730 \mathrm{G} / \mathrm{A}$ polymorphism in different stages of endometriosis patients

\begin{tabular}{|c|c|c|c|c|c|c|c|c|c|}
\hline \multirow{2}{*}{\multicolumn{2}{|c|}{ Population studied }} & \multicolumn{3}{|c|}{ Genotyping frequencies } & \multirow[t]{2}{*}{$\mathbf{P}$} & \multicolumn{2}{|c|}{ Allelic frequencies } & \multirow[t]{2}{*}{$\mathbf{P}$} & \multirow[t]{2}{*}{ OR $(95 \%$ CI $)$} \\
\hline & & GG & GA & \begin{tabular}{|l|}
$\mathbf{A A}$ \\
\end{tabular} & & G & $\mathbf{A}$ & & \\
\hline \multicolumn{2}{|c|}{ Controls without endometriosis } & $22(91.7 \%)$ & $2(8.3 \%)$ & $0(0.0 \%)$ & & $46(93.7 \%)$ & $2(6.3 \%)$ & & \\
\hline \multirow{2}{*}{ Cases } & StageI/ Stage II $(n=32)$ & $20(62.5 \%)$ & $10(31.3 \%)$ & $2(6.2 \%)$ & 0.040 & $50(76.6 \%)$ & $14(23.4 \%)$ & 0.017 & $6.4(1.40-29.88)$ \\
\hline & $\begin{array}{c}\text { Stage II/Stage IV } \\
\qquad(n=18)\end{array}$ & $8(44.4 \%)$ & $7(38.9 \%)$ & $3(16.7 \%)$ & 0.003 & $23(63.9 \%)$ & $13(36.1 \%)$ & 0.0005 & $13.0(2.70-62.53)$ \\
\hline
\end{tabular}

$O R=O d d$ 's ratio, $C I=$ confidence interval, $X 2=$ Qui square test and $P=$ Probability 


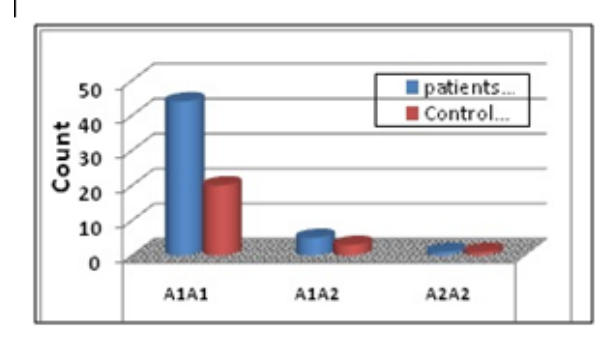

Figure 3. Genotyping frequencies of the PROINS polymorphism in endometriosis patients and controls.

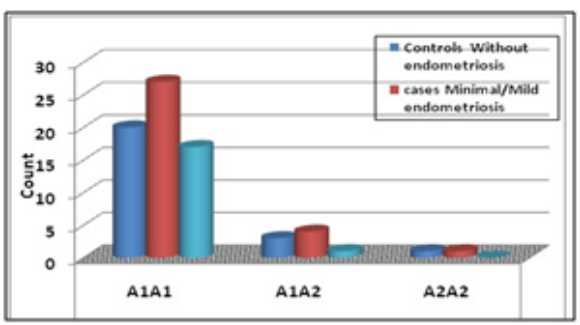

Figure 5.Genotyping frequencies of the PROGINS polymorphism in different stages of endometriosis patients.

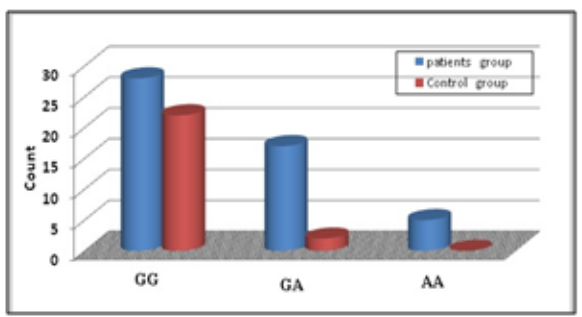

Figure 7 Genotype frequencies of the $E R \beta+1730$ $\mathrm{G} / \mathrm{A}$ polymorphism in endometriosis patients and controls.

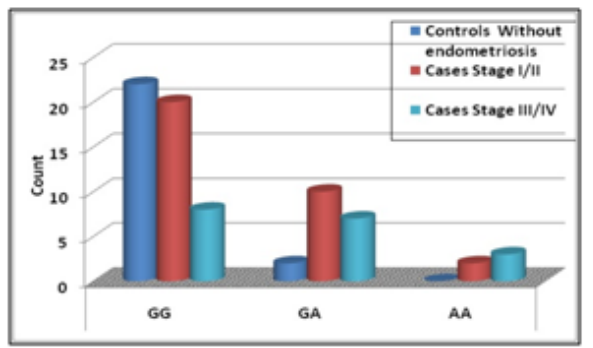

Figure 9.Genotyping frequencies of the ERR $+1730 \mathrm{G} / \mathrm{A}$ polymorphism in different stages of endometriosis patients.

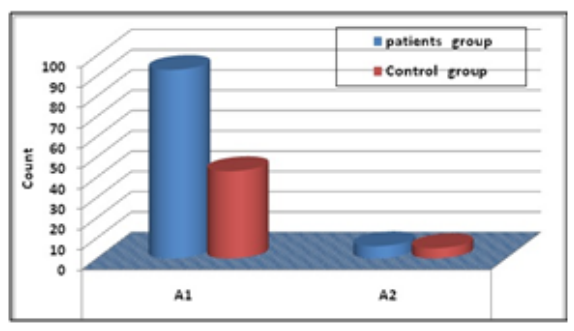

Figure 4. Allelic frequencies of the PROINS polymorphism in endometriosis patients and controls.

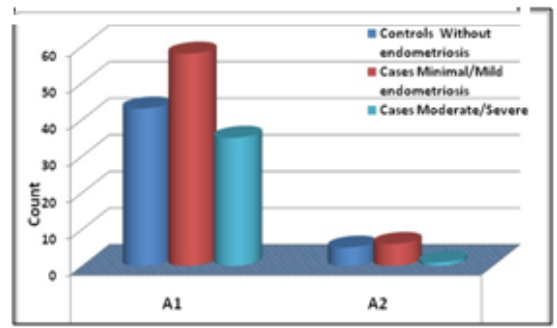

Figure 6 .Allelic frequencies of the PROGINS polymorphism in different stages of endometriosis patients.

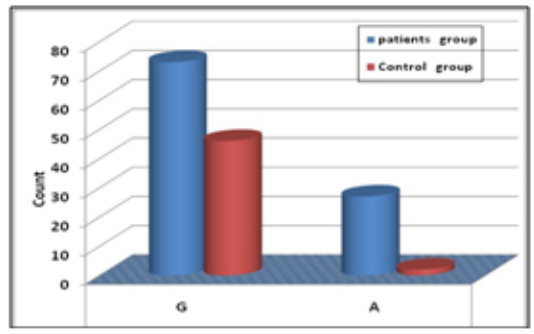

Figure 8. Allelic frequencies of the ERB $+1730 \mathrm{G} / \mathrm{A}$ polymorphism in endometriosis patients and controls

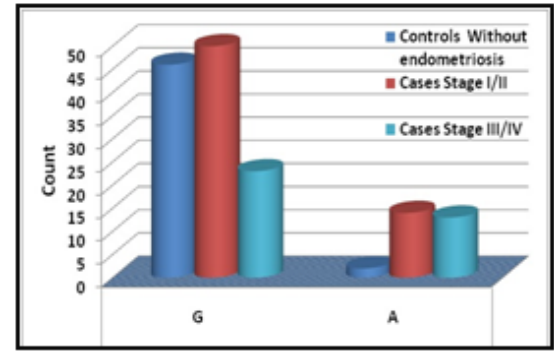

Figure 10. Allelic frequencies of the $E R b$ $+1730 \mathrm{G} / \mathrm{A}$ polymorphism in different stages of endometriosis patients

\section{Discussion}

The PROGINS polymorphism produces a decrease in the stability of the progesterone receptor gene, causing the receptor to lose its capacity to inhibit the activation of the estrogen receptors. This in turn results in an inadequate control of these receptors, thus rendering the endometrium more ulnerable to the action of estrogen. It is believed that isoform A can lead to increased expression of isoform B (which is responsible for the activation of the estrogen receptors) when it includes the PROGINS polymorphism, there by contributing to a higher oncogenic action of this polymorphism[15]. Progesterone is involved in the regulation of extracellular matrix metalloproteinases, stimulating the inhibiting factors of these enzymes; it also acts on the expression of angiogenic factors and on cell cycle-regulating factors. Moreover, D'Amora et al. [16] observed that PROGINS 
The Progins Progesterone Receptor Gene Polymorphism and Polymorphism of the Estrogen ...

variants may influence cell proliferation, viability, and apoptosis in endometrial cell metabolism. Wieser et al., [14] Lattuada et al., [17] and Carvalho et al.[18] demonstrated a significant correlation between the PROGINS polymorphism and endometriosis. On the other hand, Govidan et al. [19] concluded that the PROGINS polymorphism can be considered a risk marker for breast cancer but not for endometriosis or uterine fibrosis. Gimenes et al.[20] suggested that PROGINS is not related either to endometriosis-associated infertility or to idiopathic infertility in the population studied. Additionally, van Kaam et al. [21] concluded that the PROGINS polymorphism does not seem to modify the risk of deep-infiltrating endometriosis. In the present study, the PROGINS polymorphism was present in $12 \%$ of the patients with endometriosis-associated infertility and in $16.7 \%$ of the women in the control group $(\mathrm{p}=0.718)$. When we studied the patients with stage I/II or stage III/IV endometriosis separately, no statistical difference was found between groups ( $\mathrm{p}=0.978$ and $\mathrm{p}=0.595$, respectively). This finding suggests that the PROGINS polymorphism is not involved in the genesis of the disease in the population studied (Table 1\&2). Our results point to no association between endometriosis and the PROGINS polymorphism; however, the power calculation of the sample was low, suggesting that a larger sample is needed.

The ER $\beta$ gene is located on chromosome 14q22-24 [22]. Systemic mutation screening of the coding region and part of the 50 and 30 regions of the $E R \beta$ gene revealed two common single nucleotide polymorphisms: G/A exchange at nucleotide 1730 in the 30 untranslated region in exon 8 , and a silent $1082 \mathrm{G} / \mathrm{A}$ transition in exon 5 [23]. The functional significance of the $+1730 \mathrm{G} / \mathrm{A}$ polymorphism remains to be clarified. Although $+1730 \mathrm{G} / \mathrm{A}$ polymorphisms in the $E R \beta$ gene do not lead to amino acid changes in the ER $\beta$ protein, it is possible that these polymorphisms are in linkage disequilibrium with other regulatory sequence variations that may affect gene expression or function [24]. Furthermore, it has been recently reported that genes containing SNPs can cause different structural folds of mRNA [25]. These mRNA variants may possess different biological functions that interact with other cellular components [13]. The AluI RFLP (1730A/G) in the ESR2 gene was linked to an increased risk of stage IV endometriosis in Japanese women [26], but was not shown to influence disease susceptibility in groups of Italian and Korean women [27] .In the present study, there was a statistically significant difference between the group of infertile women with endometriosis compared to the control group, the $+1730 \mathrm{G} / \mathrm{A}$ polymorphism was present in $44 \%$ of the patients with endometriosis-associated infertility and in $8.2 \%$ of the women in the control group $(\mathrm{p}=0.003)$. When we studied the patients with stage $\mathrm{I} / \mathrm{II}$ or stage III/IV endometriosis separately, statistical difference was found between stage I/II and stage III/IV endometriosis groups and control group $(p=0.040, p=0.003)$ respectively. Our control group was carefully selected among fertile and non-menopausal women who had undergone tubal ligation for family planning reasons and who had no sign of endometriosis in their clinical history. It is important to keep in mind that the study was performed in a special group of patients, who were operated on by videolaparoscopy and, after surgery, were exposed for at least twelve months to the possibility of pregnancy, had no male factor involved in the causes of infertility and, nevertheless, did not achieve pregnancy.The deviation of genotype distribution of the patient group from HWE provid additional support for an association of the marker locus with endometriosis

Polygenic inheritance appears to be linked to the development of endometriosis, and the present study focused on the PROGINS polymorphism and the $+1730 \mathrm{G} / \mathrm{A}$ polymorphism. This search for specific molecular markers may contribute to the prevention and early diagnosis of this condition. PCR is a method that provides an accuracy of $100 \%$. The analysis for PROGINS and the $+1730 \mathrm{G} / \mathrm{A}$ polymorphism in association with endometriosis showed sensitivity of $12 \%$ and $44 \%$ respectively and specificity of $83 \%$ and $91.8 \%$, indicating a good test to rule out this pathology. When combined with other methods, its specificity and sensitivity may increase. Our group is tracking a panel of markers (that are being studied) for molecular diagnosis of endometriosis, preventing normal women from undergoing laparoscopy.

\section{Conclusion}

In conclusion, we have shown that the presence of the $E R \beta$ gene $+1730 \mathrm{G} / \mathrm{A}$ polymorphism increase the risk of infiltrating endometriosis compared to the $+1730 \mathrm{G} / \mathrm{G}$ genotype. In contrast, the PROGINS polymorphism does not seem to modify the risk of developing infiltrating endometriosis; however, the power calculation of the sample was low, suggesting that a larger sample is needed.

\section{Acknowledgement}

The authors are indebted to all the women who have contributed to this study and their families by answering the questionnaire and donating biological samples. The authors would like to acknowledge and sincerely thank the following people for their help and support: Dr. Mohammad A. Cord (Director of the Central Lab in Damietta ,Egypt) and Ramzy. E. Rashed ( chemist in Department of Toxicology, Central Lab, Ministry of Health/ Damietta, Egypt ) . 


\section{References}

[1]. Giudice LC, Kao LC. Endometriosis. Lancet. 2004;364:1789-1799.

[2]. Missmer SA, Cramer DW The epidemiology of endometriosis. Obstet Gynecol Clin North Am 2003;30(1):1-9.

[3]. Gao X, Outley J, Botteman M, Spalding J, Simon JA, Pashos CL.Economic burden of endometriosis. Fertil Steril. 2006;86(6):1561-1572.

[4]. Vigano P, Somigliana E, Vignali M, Busacca M, Blasio AM. Genetics of endometriosis: current status and prospects. Front Biosci.2007; 12:3247-3255

[5]. Ammendola M, Bottini N, Pietropolli A, Saccucci P, Gloria-Bottini F. Association between PTPN22 and endometriosis. Fertil Steril.2008;89(4):993-994.

[6]. Fabjani G, Tong D, Czerwenka K, Schuster E, Speiser P, Leodolter S, et al. Human progesterone receptor gene polymorphism PROGINS and risk for breast cancer in Austrian women. Breast Cancer Res Treat. 2002;72:131-137.

[7]. Donaldson CJ, Crapanzano JP, Watson JC, Levine EA, Batzer MA. PROGINS Alu insertion and human genomic diversity. Mutat Res.2002;501:137-141

[8]. Olive DL, Schwartz LB. Endometriosis. N Engl J Med. 1993;328:1759-1769.

[9]. Kuiper GG, Enmark E, Pelo-Huikko M, Nilsson S, Gustafsson JA. Cloning of a novel estrogen receptor expressed in rat prostate and ovary. Proc Natl Acad Sci USA. 1996;93:5925-5930.

[10]. Fujimoto J, Hirose R, Sakaguchi H, Tamaya T. Expression of oestrogen receptor-alpha and -beta in ovarian endometriomata. Mol Hum Reprod. 1999;5(8):742-747.

[11]. Diez-Perez A. Selective estrogen receptor modulators (SERMS). Arq Bras Endocrinol Metabol. 2006;50(4):720-734

[12]. Bianco B, Christofolini DM, Mafra FA, Brandes A, Zulli K, Barbosa CP. +1730 G/A polymorphism of the estrogen receptor b gene (ERb) may be an important genetic factor predisposing to endometriosis. Acta Obstet Gynecol Scand. 2009;88(12):1397-1401.

[13]. Zulli1 K, Bianco1B, Mafra1F A, Teles1 JS,Christofolini D M 1, arbosa1CPPolymorphism of the estrogen receptor b gene is related to infertility and infertilityassociated endometriosis Arq Bras Endocrinol Metab $2010: ; ; 54 / 6: 567-571$.

[14]. Wieser F, Schneeberger C, Tong D, Tempfer C, Huber JC, Wenzl R. PROGINS receptor gene polymorphism is associated with endometriosis.Fertil Steril. 2002;77:309-312.

[15]. Kieback DG, Tong XW, Weigel NL, Agoulnik IU. A genetic mutation in progesterone receptor (PROGINS) leads to an increased risk of nonfamilial breast and ovarian cancer causing inadequate control of estrogen receptor driven proliferation. J Soc Gynecol Invest. 1998; 5(1 Suppl 1):40A,

[16]. D’Amora P, Maciel TT, Tambellini R, Mori MA, Pesquero JB, Sato H, et al. Disrupted cell cycle control in cultured endometrial cells from patients with endometriosis harboring the progesterone receptor polymorphism PROGINS. Am J Pathol. 2009; 175:215224.

[17]. Lattuada D, Somigliana E, Vigano P, Candiani M, Pardi G, Di Blasio AM. Genetics of endometriosis: a role for the progesterone receptor gene polymorphism PROGINS? Clin Endocrinol. 2004;61:190-194.

[18]. De Carvalho CV, Nogueira-De-Souza NC, Costa AM, Baracat EC, Gira o MJ, D'Amora P, et al. Genetic polymorphisms of cytochrome P450cl7alpha (CYP17) and progesterone receptor genes (PROGINS) inthe assessment of endometriosis risk. Gynecol Endocrinol. 2007; 23:29-33.

[19]. Govindan S, Ahmad SN, Vedicherla B, Kodati V, Jahan P, Rao KP, et al. Association of progesterone receptor gene polymorphism (PROGINS) with endometriosis, uterine fibroids and breast cancer. Cancer Biomark. 2007;3:73-78.

[20]. Gimenes C, BiancoB, Mafra F A, Rosset V, Christofolini D M, Barbosa CP, The progins progesterone receptor gene polymorphism is not related to endometriosisassociated infertility or to idiopathic infertility CLINICS 2010;65(11):1073-1076.

[21]. Van Kaam KJ, Romano A, Schouten JP, Dunselman GA, Groothuis PG. Progesterone receptor polymorphism +331G/A is associated with adecreased risk of deep infiltrating endometriosis. Hum Reprod. 2007;22:129-135.

[22]. Enmark E, Pelto-Huikko M, Grandien K, Lagercrantz S, Lagercrantz J, Fried G, et al. Human estrogen receptor b gene structure,chromosomal localization, and expression pattern. J Clin EndocrinolMetab. 1997;82(12):4258-4265.

[23]. Rosenkranz K, Hinney A, Ziegler A, Hermann H, Fichter M, MayerW, et al. Systemic mutation screening of the estrogen receptorbeta gene in probands of different weight extremes: identificationof several genetic variants. J Clin Endocrinol Metab.1998;83(12):4524-4527.

[24]. Yaich L, Dupont WD, Cavener DR, Parl FF. Analysis of the PvuII restriction fragment length polymorphism and exon structure of the estrogen receptor gene in breast cancer and peripheral blood.Cancer Res. 1992;52(1):77-83.

[25]. Shen LX, Basilion JP, Stanton Jr VP. Single-nucleotide polymorphisms can cause different structural folds of mRNA. Proc NatlAcad Sci USA. 1999;96(14):7871-7876.

[26]. [26]. Wang Z, Yoshida S, Negoro K , et al., Polymorphisms in the estrogen receptor $\beta$ gene but not estrogen receptor $\alpha$ gene affect the risk of developing endometriosis in a Japanese population. Fertil Steril, (2004); 81, 6, 1650-1656.

[27]. Lee GH, Kim SH, Choi YM, Suh CS, Kim JG, Moon SY(2007): Estrogen receptor beta gene 1730 G/A polymorphism in women with endometriosis. Fertil Steril;88:785-788. 